\title{
CULTURAL CONQUEST OF BULGARIAN LANGUAGE FROM ANGLICISMS
}

\author{
N. Naydenova, T. Taneva
}

Trakia University, Stara Zagora, Bulgaria

\begin{abstract}
In this artcicle is shown an exchange of Bulgarian words with English ones on a large scale and the way they settle in our native speech. An accent is pointed to the use, frequency and reasons for entering of Anglicisms among politicians as well as younger generation. For the realization of the target an online survey was conducted on social networks, with a sample based on availability. The common results show that Anglicisms, enter aggressively in the Bulgarian language and this is due mainly to the work with information technology, the operativeness of speaking and their presence in the media. A higher level of English proficiency affects the increased use of foreignisms in most people. There is a short backward glance to the past and a hope for cleaning the language from entering foreign words and self-awareness.
\end{abstract}

Key words: Anglicisms, foreign words, Bulgarian language, influence

Every language is like a living organism, it grows, evolves, changes. With the development of society, cultural and historical transformations, the political situation and many other factors, the language changes its image, part of the used vocabulary disappears and a new, more modern and more widely used is placed in its place. The most powerful example of this is the use of an extremely large number of Turkish words known to every Bulgarian immediately after the Liberation.

Later, they were displaced by Russian concepts and terms coming in strong in Bulgaria for about 45 years, with the construction of factories, roads, and many public buildings on a Russian model. For example, the word "cooperative" with a dictionary meaning is quickly adopted: 1 . Collective production, trade or construction union, created with the resources of its members. 2. In the case of socialism - laborfarm economy (Dictionary of the Bulgarian language,2010). "Sociological propaganda is the creation of preconditions for conducting the political. ... The process of linguistic assimilation can be compared with the entry of Turkish into the Bulgarian. "(Kutevski, 2004). The author asserts that at the beginning of Turkish slavery, the Turkish is accepted forcibly and not utilitarianly . In this case, it can be talked about psychological violence as well as its use as a mechanism for "preservation through interaction" (trade, occupation of management positions by Bulgarians, etc.). In his view, Kutevski (2004) considers that the penetration of Russianisms is also not dictated by objective necessity, but by violent and assimilative historical processes through propaganda, due to "the strong politicization of public life in the period 19451955 ".(Kutevski, 2004)

In the last 30 years, there has been an avowed and increasingly strong English and American influence on language, culture and technologies. Again Kutevsky (2004) poses the question in Bulgarian linguistics about this new "sphere of influence" over our language after the democratic changes in 1989 in Bulgaria. He sees this process as a linguistic innovation as a result of social transformation and as a consequence of the globalization associated with the "invasion of American culture globally". Some of the authors name the process "language genocide" towards national languages serving the goals of multinational companies (DirkGeerets, Kutevski, 2004). 
English has become the language through which the world communicates, the language of change, industrialization, politics, computers, education, technology, and so on. In general, the English language is everywhere: from the sign of the shop door Open to the exit of the airport HAVE A NICE FLIGHT, from the mat in front of our home door WELCOME to the exit of the cinema or the theatre EXIT.However, everything is clear to everyone, and children understand what is the sign meaning.The question arises - How people who do not know English feel in their own country when they read everything in a foreign language?

Foreign English words enter and settle freely and naturally in our language and sometimes, unfortunately, displace the Bulgarian words from speech.

There is another trend, especially among politicians and the senior echelon, to use words to conceal, not to explain the actions. In such cases, they talk very much and say nothing, many words, but no information, but the more incomprehensibly they talk about, the better they achieve their goal. Often, the representatives of the political elite strive to use the foreignisms purposefully, but also with the idea that the audience not to understand fully the meaning of their speech, but to be impressed by the lore and the high capacity of the speaker.

Of course, it is clear to linguists that the use of foreignisms does not mean a high linguistic culture and competence.

It is becoming modern in these spheres to use too many foreignisms at the expense of the beautiful Bulgarian speech. It is too common, for example, to use the word колаборация from English collaboration (сьтрудничество, съвместна работа), even from people who do not know its meaning.According to Popova (2013), "sometimes foreign words, even when they are part of the international vocabulary, make understanding difficult because they are unknown to the audience. The presumption (that's one word) that all or most people understand them is not correct. Considering that foreign language proficiency, although recommended, offered and encouraged especially in recent years, is not among the strengths of the average reader, foreign words are either not well understood or misunderstood. Kutevsky (2004) develops the idea that "From the propensity of language to
NAYDENOVA N., et al.

be assimilated can also be thought for the public attitude towards foreign ideological influence." According to him, entering of new ideas, euphemisms and political metaphors, which become desirable and fashionable, is related to the natural aspirations of Bulgarians to be part of societies with a higher standard of living. Many examples can be discussed, such as "евроинтеграция" "european integration", “кохезионни политики" "cohesion policies", “мобилност"”mobility" and others.

Of course, we can not avoid so-called international vocabulary such as ATM, account, tablet, software, online, euro, SMS and others, which according to linguists and university lecturer Assoc. Prof. Teofana Gaidarova,PhD (2004) "Is an irreversible process that has been running since antiquity and without which communication would have been impossible." According to her, 200 to 500 new words come into our language per year, and after 2000 year two dictionaries of the new words and their meanings have been published - in 2001 and in 2010. Scientists from the Bulgarian Language Institute at the Bulgarian Academy of Sciences have researched nearly 7,000 electronic documents containing about 250 million words from different thematic areas (Gaidarova, 2004).

At the same time there are many foreignisms which are so actively used that we do not notice there are Bulgarian words about them: situation(положение), absurd (безсмислица), reason (право), consensus(сьгласие), correction (поправка),etc. (Kirilov,2017). According to Gaidarova (2017), however, there are foreignisms which should be ignored because of the purity of the language: event (събитие), lifestyle (начин на живот), fashion (мода), trend (тенденция), support (подкрепям), like (харесвам), user (потребител, ползвател).

Today in Bulgarian language there is a massive use of foreignisms mainly from English, especially among the younger generation mainly in the sphere of technology, computers, Internet, so-called "Chatter language" (Desimirova, 2019). Words such as upgrade, copy, paste, join, update, etc. entered into general use through it.Youth literally talk like this: "Мога ли да се джойна при вас? (Can I join you) "when it refers to computer games. They not only speak in that way, they also write Bulgarian words in Latin, replacing sounds and letters with numbers and characters 
from the keyboard. (ch - 4, sh - 6, etc.) Another typical trend coming from English and American films and music, as well as the entirely spoken style, are appeals such as май бро, май френд, , мен, братър, etc. entered literally. Thus foreign words remain and settle successfully in the language, and afterwards next generations will perceive them as Bulgarian.The influence of the Anglicisms is so strong and irreversible that they create new word forms, despite the resistance of linguists and philologists. These foreign words for Bulgarian language get some grammatical categories like gender, number, tense, definite or indefinite article, and thus they become an equal part of the language, without associating them deliberately with ideas like patriotism and national identity.

A lot of Bulgarian philologists have fought for the purity of the Bulgarian language. Sometimes they sound a little funny with ideas of not accepting foreign words. They have created new Bulgarian words instead of foreignisms. It was funny for someone when Ivan Bogorov created "драсни пални клечица", instead of a match because he has considered the language as a holy thing. Alexander Teodorov - Balan, one of the founders of Sofia University and his first rector, is also a true supporter of the purity of the Bulgarian language. He is the author of new words such as "възглед", "влак", "заплаха", "излет," "общувам", "предимство", "украса" and many others to replace the foreignisms (Gaidarova2004). He is one of those of our writers before and after the Liberation, who has built up the vocabulary of the language.

Their idea is not only in the past. Many groups have been formed on the Internet recently with a basic idea of discussing the purity of the language. The adherents find foreigners in speech, give their Bulgarian meaning or word, build a culture of opposition to the users of predominantly English, and support the use of Bulgarian instead of English words. Philologists and scientists from the Bulgarian Academy of Sciences are studying the language of politicians and youth, writing articles about the invasion of Anglisisms in Bulgarian language, creating dictionaries of new words and foreign words, but the trend is very strong. In these groups are quoted the verses of writers of the Bulgarian national Revival, authors such as Vazov, Yovkov and Ran Bosilek, written in response to the
NAYDENOVA N., et al. unanimous assertions of rudeness and nonmusicality of our language after the Bulgarian Revival. The purpose of such an activity is to form self-consciousness, patriotism, love of language, state, nationality, give a meaning of values. In this sense Deleva (2003) recalls the thesis of the Bulgarian writer Y. Yovkov: "The word is an amazing thing. It closes itself all the means of expression of all arts: paints, lines, forms, sounds, movements - everything, if you only knew how you can handle these riches". "Our language is so beautiful, pretty, lovely, charming, beloved, exquisite, gorgeous, picturesque, wondering, so, if we dare to complain about lack of synonyms or monotony, somebody must rebuke and cheer us up well." (Deleva)

According to Eagleton, it does not matter whether the causes of linguistic invasion are defined as cultural or ideological - the fact is that both frames are determinant sources of public influence, that foreign words will sooner or later change the whole social context (Eagleton, 2003, by Kutevsky, 2004).

In more than 28 European countries, a law on the protection of the purity of language is enforced and monitored by the Ministry of Justice and Education. Lithuania, Latvia and Estonia provide to create special committees to monitor the purity and literacy of the official language." There is a Polish Language Council in Poland that prepares reports for the parliament. Particularly prominent in this respect is France, where for more than 20 years the Tubon law, protects French from the English-language linguistic invasion at work, in trade, advertising, etc. In Bulgaria during last 20 years, the law of Bulgarian language has been rejected. A lot of bills were created but not passed. Nikolay Haytov is one of the first compilers of such a bill, Yordan Sokolov, Prof. Lyuben Kornezov, Prof. Stanislav Stanilov and others". (Dankov, 2015)

Since the entering of Anglicisms into the Bulgarian language is most common among young people, it is interesting their opinion on that question, as well as the real practice of using Anglicisms in their everyday life.

\section{METHOD}

For the realization of the target in the period June- July 2019 an online survey was conducted on social networks, among 106 surveyed individuals, with a sample based on availability. The questionnaire consists of 28 questions with Likert type answer rows, six of 
which are composed (between 5 and 30 questions) and 4 open questions, structured in five modules:

(a) use of the most commonly used Anglicisms; b) reasons for their entry into the Bulgarian language; c) the use of foreignisms by the popular media and the political elite; d) level of proficiency in foreign languages and in the Bulgarian language; (e) demographic issues

Sample Description:

People surveyed are aged $18-40,78 \%$ are women, and $22 \%$ are men distributed by education as follows:

$60.4 \%$ - with higher education,

36,8 - secondary education,

- living mainly:

$81.1 \%$ in district towns,

$15.1 \%$ - in a smaller town,

$2.8 \%$ - in the village
NAYDENOVA N., et al.

- most often with proficiency in one foreign language $-56.6 \%$

- the main foreign language that they have studied at school is English, at an average level of $50.9 \%$

\section{RESULTS}

Words, most often replaced: started (instead of започвам); cash (instead of в брой); finance (instead of подпомагам с пари); localization (instead of местоположение); okay (instead of добре); manager (instead of управител); stimulate (instead of подкрепям); invest (instead of влагам пари); party (instead of събиране); minimum (instead of най-малко); maximum (instead of най-много); exotic (instead of необичаен); online (instead of в интернет); nonstop (instead of непрекъснато)

(Figure 1).

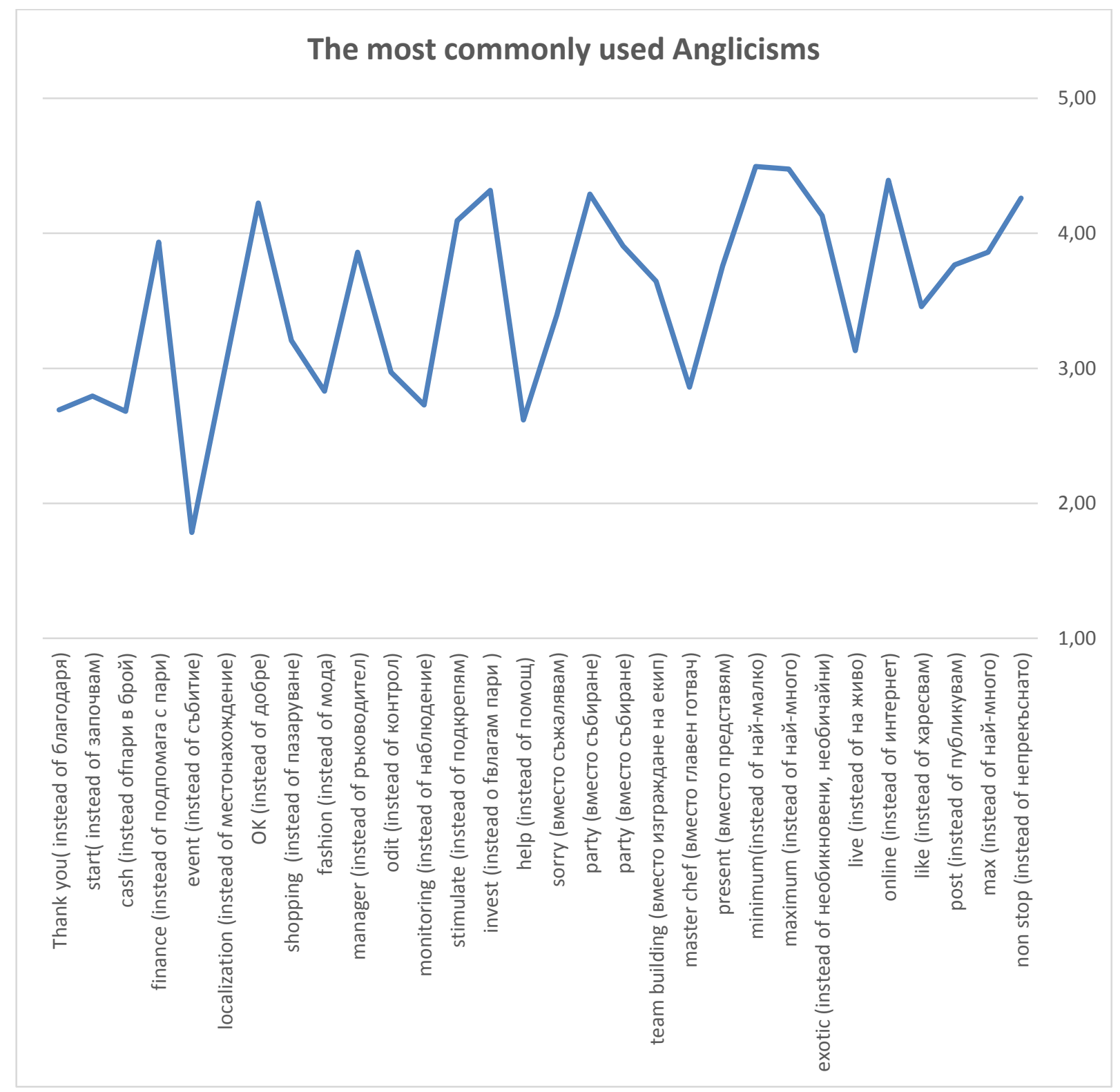

Figure 1. 
In free text, respondents added the words Report (instead of доклад), Нарру (щастлив); Cool (готиноl); Hello, Copy, Paste,
Innovation,Super, Bye, Yes, Brand, Hate, Scroll, etc.

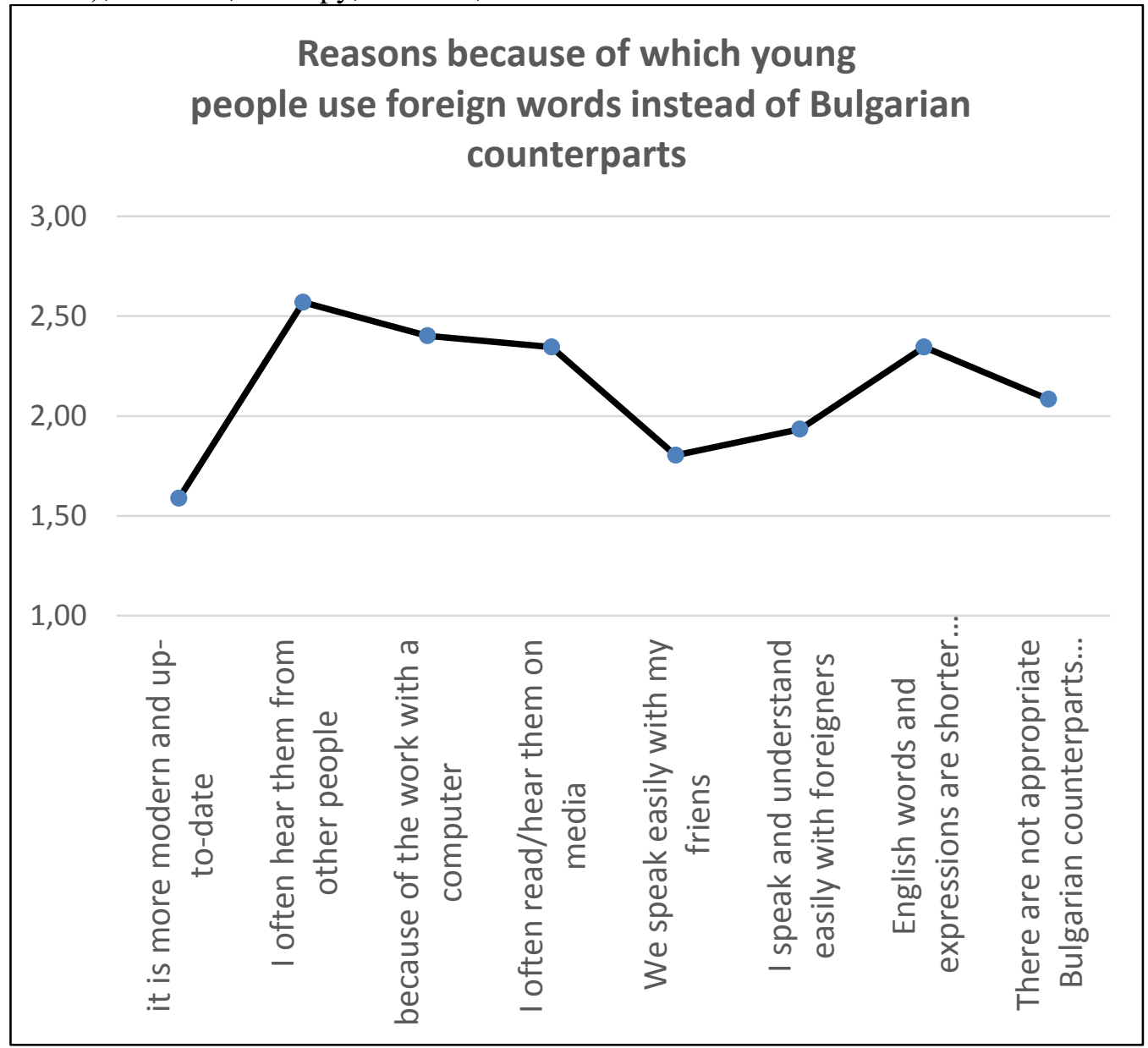

Figure 2.

The answers for the reasons why young people claim to use foreign words instead of Bulgarian counterparts are piled around the allegations: (Figure 2):

"I very often hear them from others";
"I got used to working with the computer"; "I hear them in the media"; "they are shorter than the Bulgarian words"; "there are no suitable Bulgarian words".

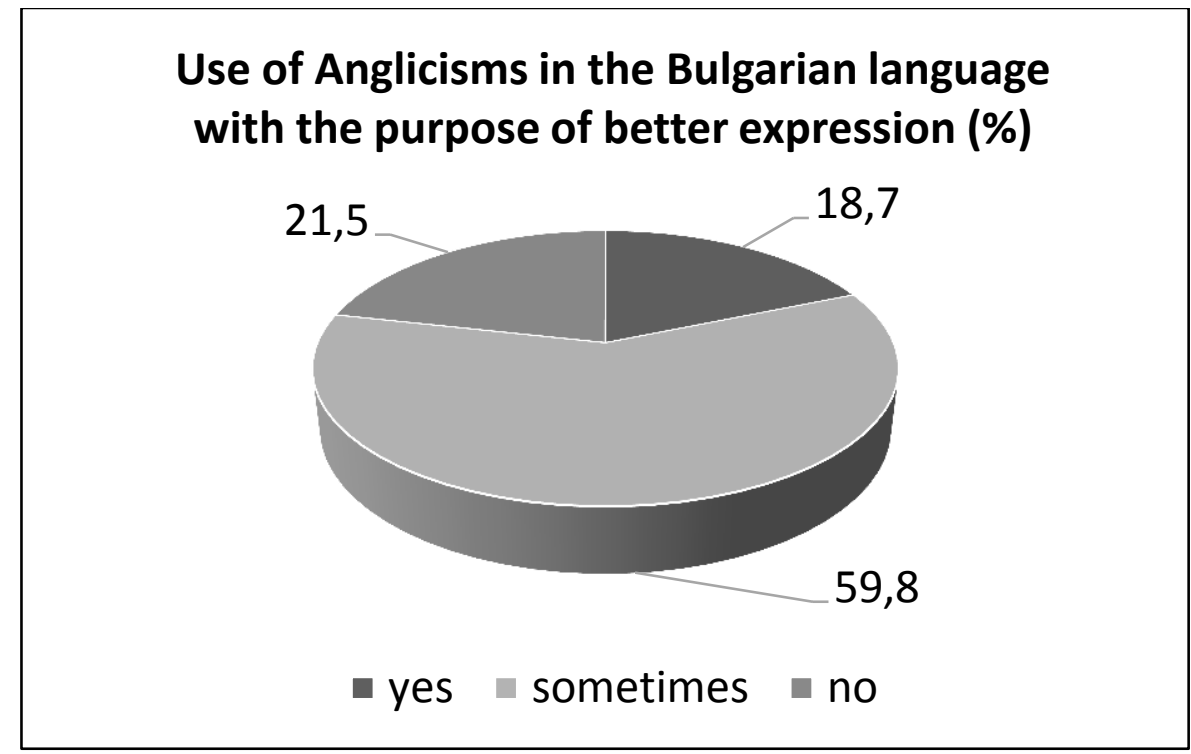

Figure 3. 
From the information provided in open text by the respondents to the open questions, it can be summarized that the reasons for using foreign words instead of Bulgarian are "the professional language in their work" and" their wide use in daily contacts and the media".

To the question "Do foreignisms help you to express yourself better?" the largest share of respondents replied: "sometimes" (59.8\%),
NAYDENOVA N., et al. and about $1 / 5$ answered equally "yes" and "no" (Figure 3).

At the same time, respondents make negative judgments for those using foreign words, and $63.2 \%$ of young people are not left with a good impression on them (Figure 4).

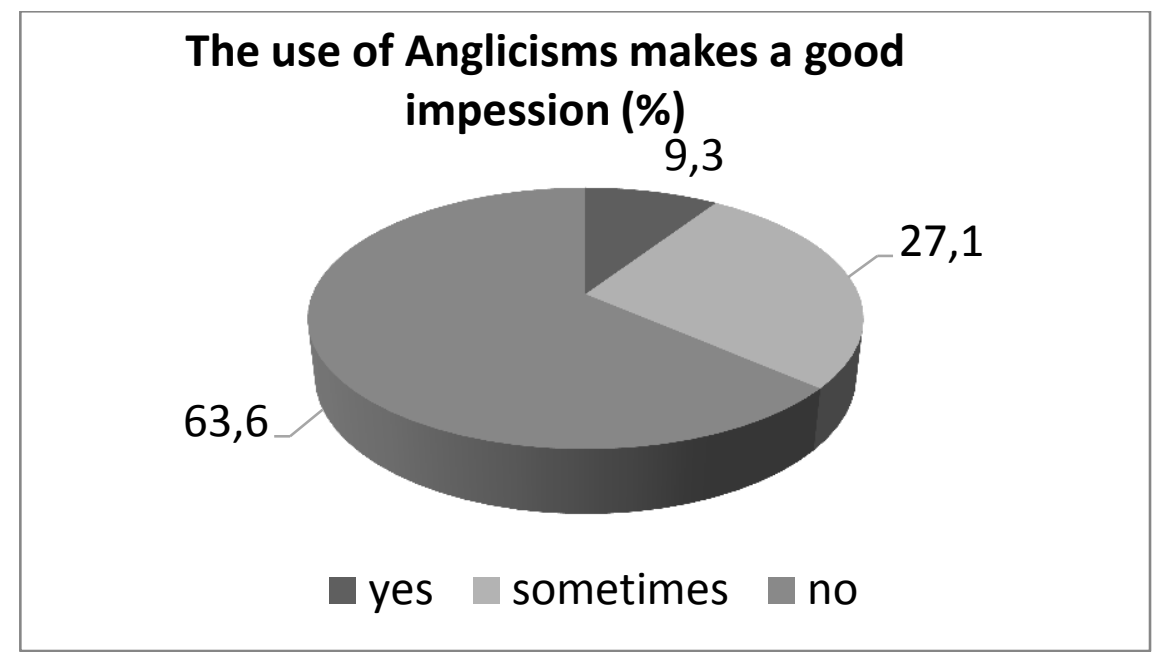

Figure 4.

To the question, "Which people do you think use more foreign words?" most of the answers are about: "younger people",

"who knows more foreign languages" and "people with more contacts" (Figure 5).

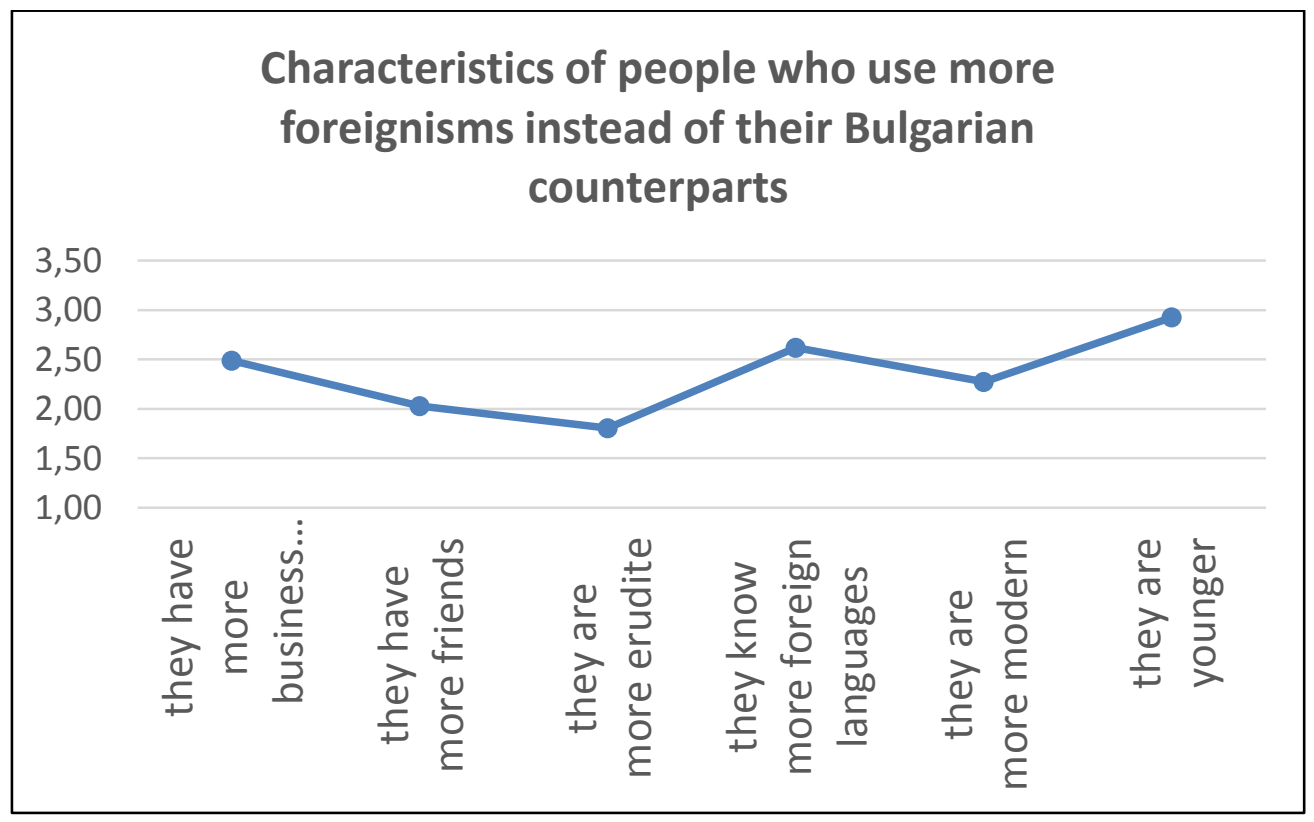

Figure 5.

Other answers to this question are:

"users of foreignisms read more often in English",

"the social environment requires it" or "someone who has a poor vocabulary".

One of the focuses of the study is the influence of the linguistic behavior of politicians and the media on the use of foreignisms by young people. Regarding the use of foreignisms by politicians, the question: "How often does this happen?", Half of respondents - $56.6 \%$ say that they are often used (Figure 6). 


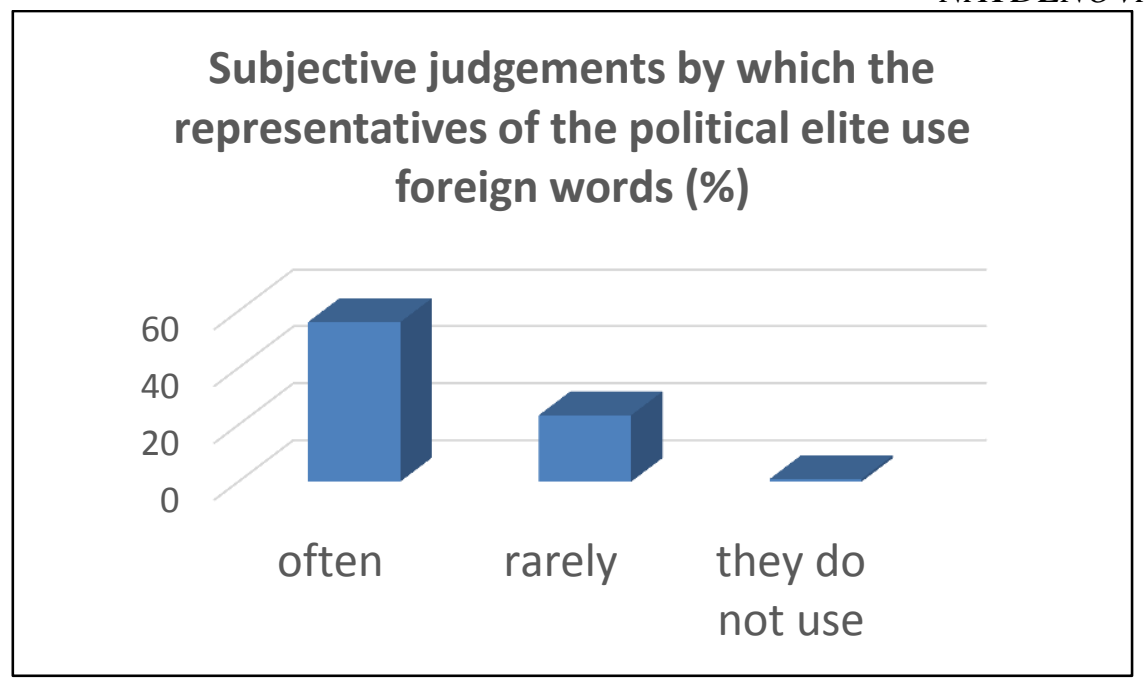

Figure 6.

According to respondents, politicians use foreign words, especially to look modern, high experts, to get closer to young voters, to imitate pomposity and importance or they are not able to select the correct lexical unit because of low level of Bulgarian proficiency. (Figure 7).

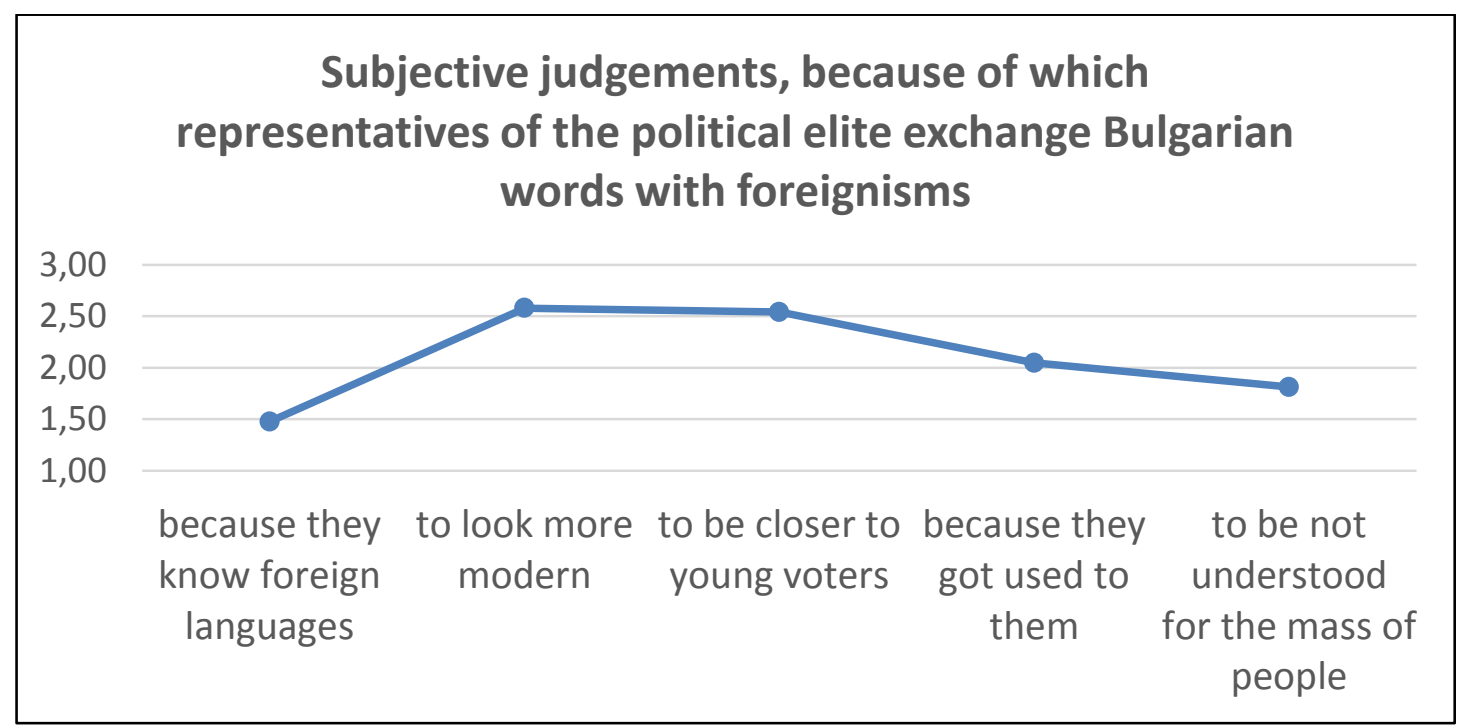

Figure 7.

To the question "Do you think politicians use foreign words instead of Bulgarians deliberately?", $48.1 \%$ of young people answer affirmatively. (Figure 8).

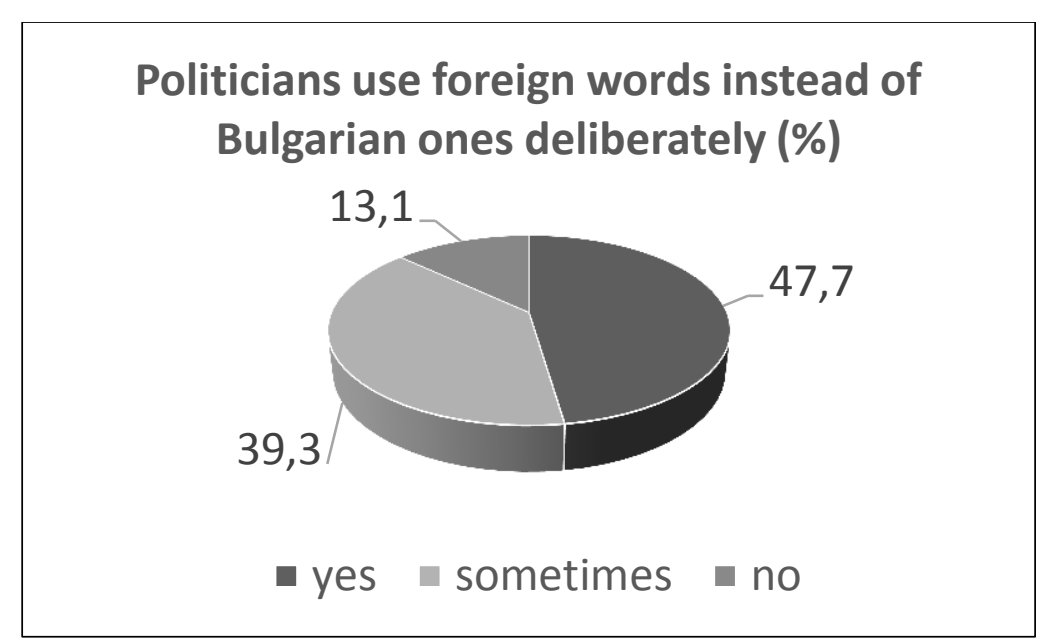

Figure 8. 
At the same time, more than half of respondents $(55.7 \%)$ state that the use of foreign words on media and by politicians is irritating to them. (Figure 9).

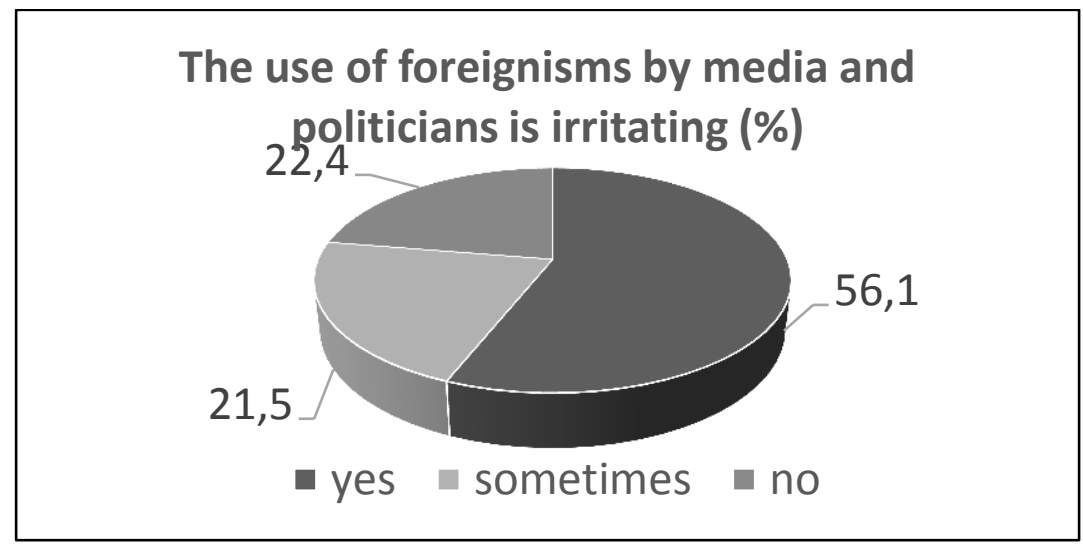

Figure 9.

In general, the attitude towards the exchange of Bulgarian words with foreignisms by the media and politicians is negative - for $67.9 \%$ of the surveyed people (Figure 10).

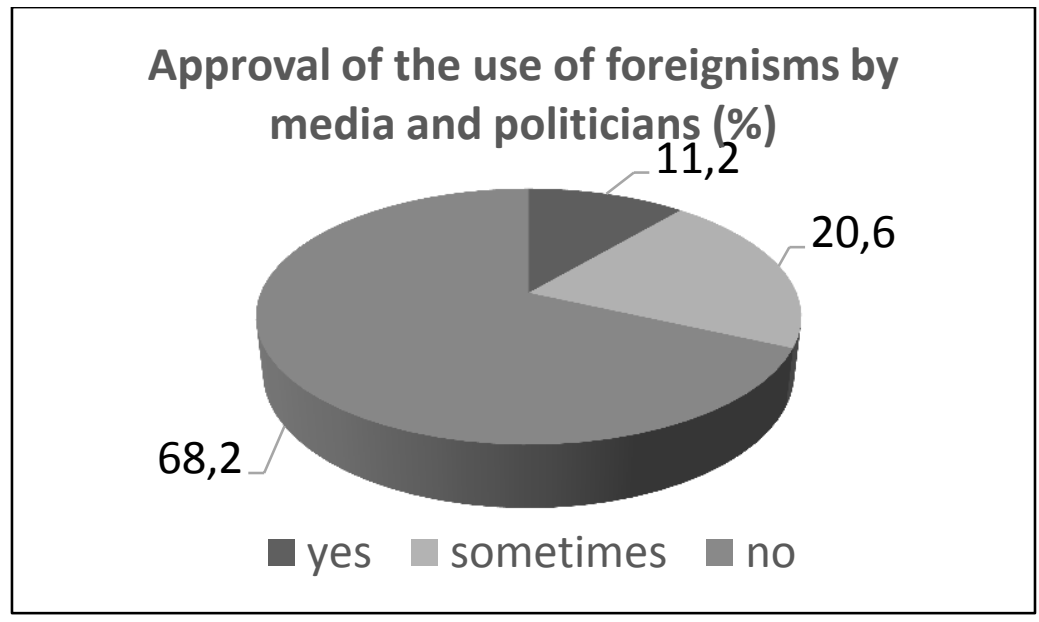

Figure 10.

Some additional parameters of the attitude of young people towards foreignisms in the language are investigated, which outline the following: Their daily business contacts are mostly with
Bulgarians only - $69.8 \%$, and not a small part about $30 \%$ contacts with foreigners and with Bulgarians (Figure 11).

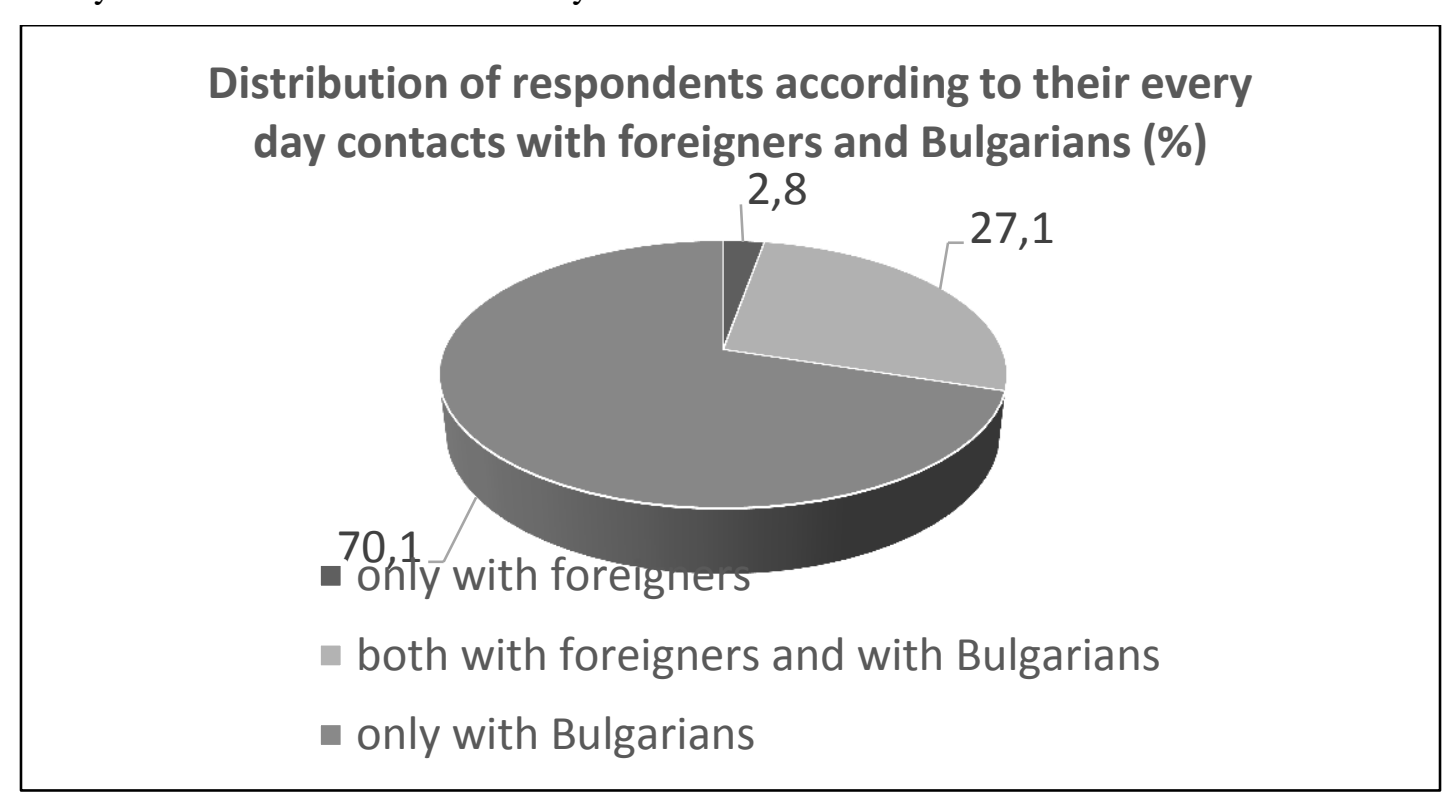

Figure 11. 
At the same time, the programs most commonly used on the computer and on the phone are mainly in English for a very large part (almost $80 \%$ ) of the respondents (Figure 12), and the
NAYDENOVA N., et al. most frequently downloaded Internet materials are films and programs that have more direct relation to reading, listening and understanding of the foreign language (Figure 13).

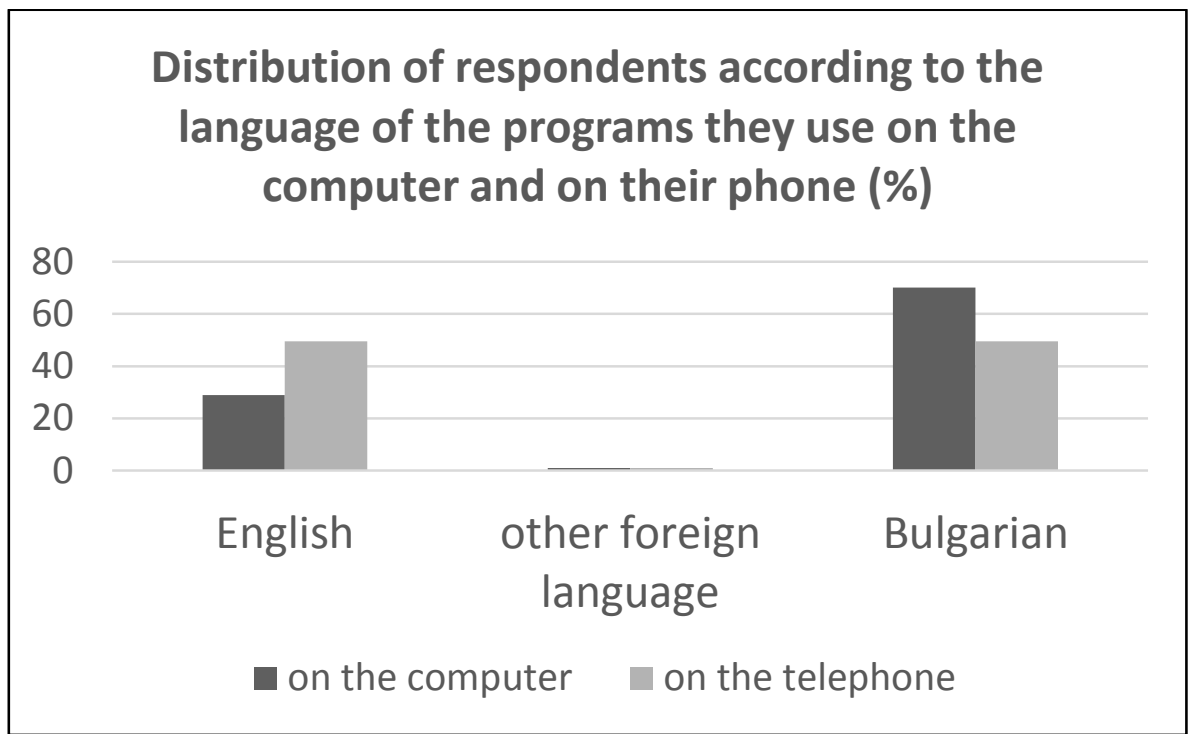

Figure 12.

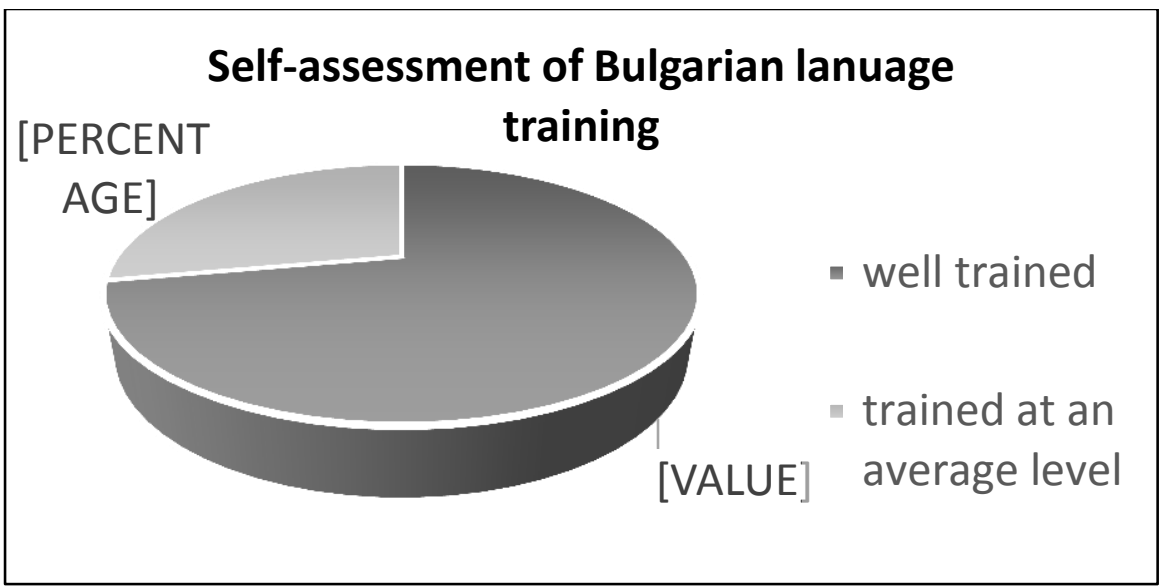

Figure 13.

It is a pre-working hypothesis that the attitude towards the purity of the language is related to the extent to which young people are well trained in a native language, reading fiction or scientific literature. It turns out that they feel well trained in Bulgarian and more than half have declared that they often read fiction, but only about $30 \%$ - scientific literature, in electronic or paper version (Figure 14 Figure 15).

\section{Frequency with which respondents read fiction}

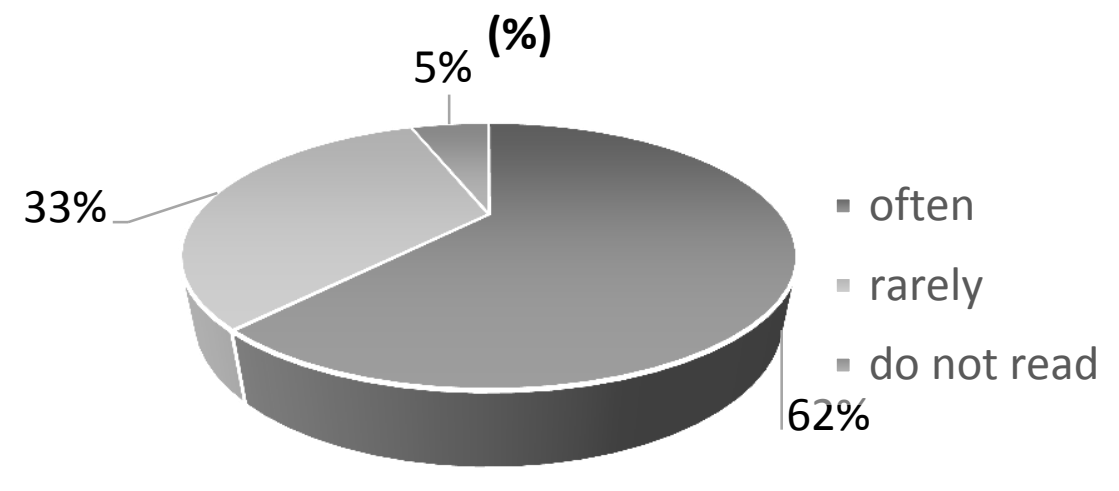

Figure 14. 
The results of the dispersion analysis find an influence of foreign language level proficiency
NAYDENOVA N., et al. and the public use of the Anglicism on the use of foreignisms by young people.

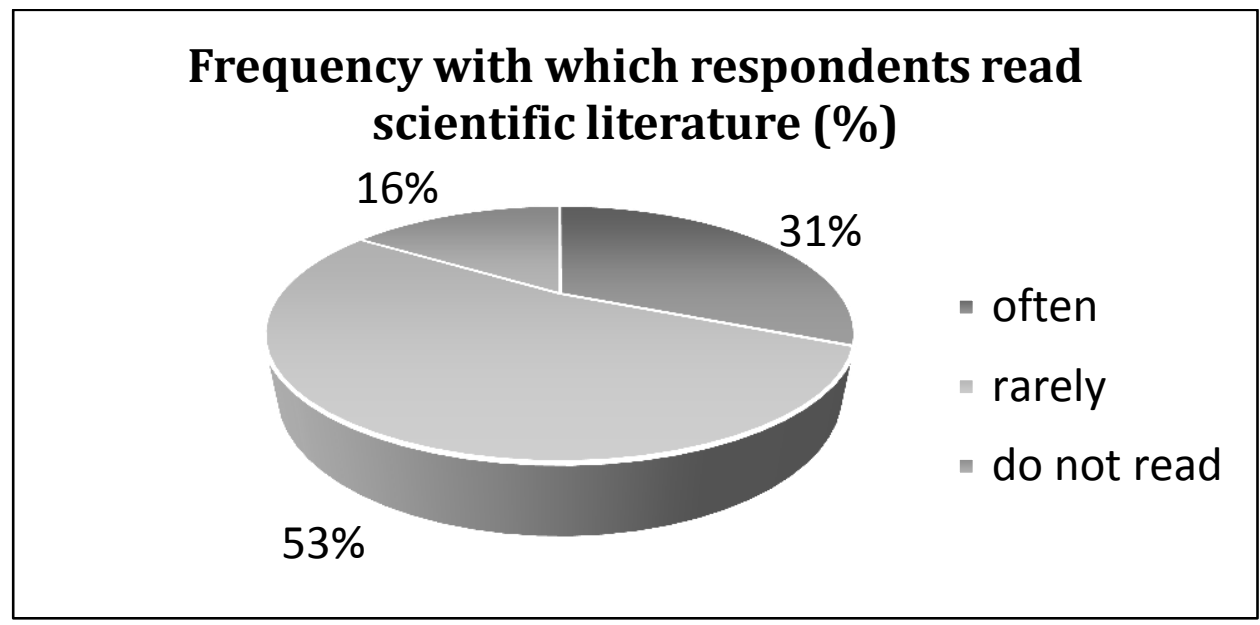

Figure 15.

It appears that a higher level of English proficiency has a statistically significant impact (Table 1, ANOVA, at $\mathrm{p}<0.05$ ):

- more frequent use of Anglicism by young people $(\mathrm{F}=3.50)$

- their less influence on the environment $(\mathrm{F}$ $=5.11$ )

- their self-assessment for a richer vocabulary $(F=7.69)$; their opinion that in many cases there are no suitable Bulgarian words $(\mathrm{F}=5,36)$, that Anglicism is a better way of expressing $(F=4,97)$ and that they serve more frequent business contacts with foreigners $(F=20,11)$, and that they are used to download English programs to devices ( $\mathrm{F}=$ 7.96).

Table 1. Influence of Foreign Languages on the Use of Anglicisms (ANOVA)

\begin{tabular}{|c|c|c|c|c|}
\hline $\begin{array}{l}\text { Independent } \\
\text { variable }\end{array}$ & Dependent variable & $\begin{array}{l}\text { Language } \\
\text { proficiency } \\
\text { level }\end{array}$ & $\mathrm{X}$ av. & ANOVA \\
\hline \multirow{9}{*}{ 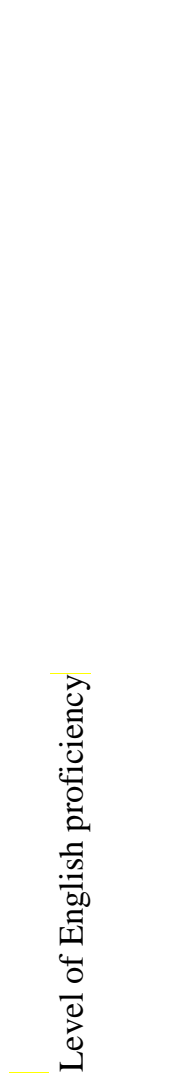 } & Frequency of use of foreigners & $\begin{array}{l}\text { Low } \\
\text { On average } \\
\text { High }\end{array}$ & $\begin{array}{l}\mathrm{x} 1=3,37 \\
\mathrm{x} 2=3,45 \\
\mathrm{x} 3=3,80\end{array}$ & $\begin{array}{l}F=3,50 \\
p<0,05\end{array}$ \\
\hline & Influence of the environment & $\begin{array}{l}\text { Low } \\
\text { On average } \\
\text { High }\end{array}$ & $\begin{array}{l}\mathrm{x} 1=2,71 \\
\mathrm{x} 2=2,66 \\
\mathrm{x} 3=2,31\end{array}$ & $\begin{array}{l}F=5,11 \\
p<0,05\end{array}$ \\
\hline & $\begin{array}{l}\text { They do not find the } \\
\text { appropriate Bulgarian words }\end{array}$ & $\begin{array}{l}\text { Low } \\
\text { On average } \\
\text { High }\end{array}$ & $\begin{array}{l}x 1=1,66 \\
x 2=2,07 \\
x 3=2,37\end{array}$ & $\begin{array}{l}F=5,36 \\
p<0,05\end{array}$ \\
\hline & $\begin{array}{l}\text { Foreignisms help for better } \\
\text { expression }\end{array}$ & $\begin{array}{l}\text { Low } \\
\text { On average } \\
\text { High }\end{array}$ & $\begin{array}{l}\mathrm{x} 1=1,61 \\
\mathrm{x} 2=2,00 \\
\mathrm{x} 3=2,15\end{array}$ & $\begin{array}{l}F=4,97 \\
p<0,05\end{array}$ \\
\hline & $\begin{array}{l}\text { Have more than one foreign } \\
\text { language }\end{array}$ & $\begin{array}{l}\text { Low } \\
\text { On average } \\
\text { High }\end{array}$ & $\begin{array}{l}\mathrm{x} 1=1,05 \\
\mathrm{x} 2=1,46 \\
\mathrm{x} 3=2,06\end{array}$ & $\begin{array}{l}F=18,22 \\
p<0,05\end{array}$ \\
\hline & $\begin{array}{l}\text { Business contacts with } \\
\text { Bulgarians and foreigners }\end{array}$ & $\begin{array}{l}\text { Low } \\
\text { On average } \\
\text { High }\end{array}$ & $\begin{array}{l}\mathrm{x} 1=1,10 \\
\mathrm{x} 2=1,16 \\
\mathrm{x} 3=1,75\end{array}$ & $\begin{array}{l}F=20,11 \\
p<0,05\end{array}$ \\
\hline & $\begin{array}{l}\text { Device programs are in a } \\
\text { foreign language }\end{array}$ & $\begin{array}{l}\text { Low } \\
\text { On average } \\
\text { High }\end{array}$ & $\begin{array}{l}\mathrm{x} 1=2,04 \\
\mathrm{x} 2=2,29 \\
\mathrm{x} 3=2,84\end{array}$ & $\begin{array}{l}F=6,25 \\
p<0,05\end{array}$ \\
\hline & Rich vocabulary in Bulgarian & $\begin{array}{l}\text { Low } \\
\text { On average } \\
\text { High }\end{array}$ & $\begin{array}{l}\mathrm{x} 1=2,23 \\
\mathrm{x} 2=2,29 \\
\mathrm{x} 3=2,71\end{array}$ & $\begin{array}{l}F=7,69 \\
p<0,05\end{array}$ \\
\hline & Download Device Programs & $\begin{array}{l}\text { Low } \\
\text { On average } \\
\text { High }\end{array}$ & $\begin{array}{l}\mathrm{x} 1=2,04 \\
\mathrm{x} 2=2,39 \\
\mathrm{x} 3=2,53\end{array}$ & $\begin{array}{l}F=3,30 \\
p<0,05\end{array}$ \\
\hline
\end{tabular}


The more frequent use of foreignisms by politicians influences statistically significant on (Table 2):

- more frequent use of Anglicisms by young people $(\mathrm{F}=3.84)$

-their opinion that politicians use them to look more modern and up-to-date $(\mathrm{F}=3.52)$
NAYDENOVA N., et al.

There is another interesting relationship:

Young people, who express a moderate stand in their statement that politicians rarely use foreignisms, are more moderate in their emotional response to irritation when they hear the use of foreignisms $(F=5,48)$.

Table 2. Influence of the use of Anglicisms by Politicians on the use of Young People (ANOVA)

\begin{tabular}{|c|c|c|c|c|}
\hline $\begin{array}{l}\text { Independent } \\
\text { variable }\end{array}$ & Dependent variable & $\begin{array}{l}\text { Language proficiency } \\
\text { level }\end{array}$ & $\mathrm{X}$ av. & ANOVA \\
\hline \multirow{3}{*}{ 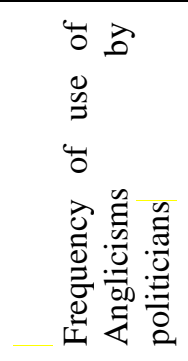 } & $\begin{array}{l}\text { Frequency of use of } \\
\text { foreignisms }\end{array}$ & $\begin{array}{l}\text { They do not use } \\
\text { They rarely use } \\
\text { They often use }\end{array}$ & $\begin{array}{l}\mathrm{x} 1=1,61 \\
\mathrm{x} 2=3,48 \\
\mathrm{x} 3=3,51\end{array}$ & $\begin{array}{l}F=3,84 \\
p<0,05\end{array}$ \\
\hline & $\begin{array}{l}\text { They use them to } \\
\text { look more modern }\end{array}$ & $\begin{array}{l}\text { They do not use } \\
\text { They rarely use } \\
\text { They often use }\end{array}$ & $\begin{array}{l}\mathrm{x} 1=2,00 \\
\mathrm{x} 2=2,30 \\
\mathrm{x} 3=2,73\end{array}$ & $\begin{array}{l}F=3,52 \\
p<0,05\end{array}$ \\
\hline & $\begin{array}{ll}\text { It is irritating } & \text { when } \\
\text { politicians } & \text { use } \\
\text { foreignisms } & \end{array}$ & $\begin{array}{l}\text { They do not use } \\
\text { They rarely use } \\
\text { They often use }\end{array}$ & $\begin{array}{l}\mathrm{x} 1=3,00 \\
\mathrm{x} 2=1,92 \\
\mathrm{x} 3=2,52\end{array}$ & $\begin{array}{l}F=5,48 \\
p<0,05\end{array}$ \\
\hline
\end{tabular}

In contrast, young people who think that politicians do not use or often use Anglicisms are much more annoyed by their use.

\section{CONCLUSIONS}

1. Anglicisms, which are most commonly used by young people, enter aggressively in the Bulgarian language.

2. This is due to the work with information technology, the operativeness of speaking and their presence in the media.

3. There is criticism about the use of Anglicisms, even in people who use them often.

4. A higher level of English proficiency affects the increased use of foreignisms in most people.

5. Anglicisms are often used by politicians and mass media, which is emotionally negative for young people.

In conclusion, we can say that Bogorov, Balan, Andreychin, Mladenov's persuasions are live, people can assert themselves, be knowledgeable and capable, while taking care of the purity of the Bulgarian language, which is an expression of national identity.(Andreichin). Foreign languages are wealth, but keeping the native language pure is dignity.

\section{REFERENCES}

1. Andreychin, L. Bulgarian language, IV. 1954, book. 4, p. 308.
2. Boychev, Boyan. „Общувам вместо комуникирам”, 2015, в. Дума, бр. 245

3. Dankov, Boris, „How long will the language low be passed?"(2015)

4. Deleva, Marina. „10 the most frequently used foreignisms and their Bulgarian greatgrandmothers", 2017

5. Desimirova, Neli "Loan words and foreignisms in the Bulgarian language", 2019

6. Eagleton 2003: Eagleton, T. The idea for culture. Sofia: IC "Criticism and humanism", 2003

7. Gaydarova, Teofana. "Live contributions of Alexander Teodorov Balan in the theory of Bulgarian linguistic culture" Scientific works of PU "P. Hilendarski", vol.42, book1, 2004Philologies.

8. Kirilov, Kiril. „Why do we have to use words like smutty and selfy but ignore event and lifestyle?", 2017

9. Kochev, Plamen. „Those foreign words that have displaced the Bulgarian ones" 2018,Lifebites

10. Kutevski, Boyan. "The entering of Rissianisms into Bulgarian language as an instrument of sociological propaganda", 2004

11.Popova, Diana. „For the use of English words in Bulgarian press - invasion, globalization or a pretention", fund „scientific researches" - Ministry of Education and Science 63, 2013

12. Geeraets, D. CulturalModels of LinguisticStandardization. // <http://wwwling.arts.kuleuven.ac.be/gling/Cu ltural $\% 20$ models $\% 20 \mathrm{of} \% 20$ linguistic $\% 20$ stan dardization.pdf> (29.09.2004). 